\title{
Membaca Arena Baru Subpolitik Anak Muda dalam Memaknai Risiko Industri Ekstraktif
}

\author{
Erwinton Simatupang, Vandy Yoga Swara
}

\author{
Departemen Pembangunan Sosial dan Kesejahteraan FISIPOL UGM
}

erwinton.simatupang@gmail.com | vandyyogas@gmail.com

\begin{abstract}
This article reveals the dynamics of youth subpolitics engagement amidst concern about environmental, social and economic risks of extractive industry operations. By focusing specifically on one of industrial locations as a case study, we explore how young people reflect nowadays and future various risks. This research uses a qualitative method with descriptive approach. Data is collected through focus group discussion (FGD), interview, and documentation. Behind youth subpolitics engagement discourse, we found that a change designed by young people leads to the risks. At this point, youth subpolitics engagement attempts to capitalize the risks that they initially against. At micro level, it turns out that a dominant actor controls youth subpolitics engagement. Applying the theoretical approach of strategic action fields developed by Neil Fligstein and Doug Mc Adam, we analyze how the dominant actor changes an arena of youth subpolitics engagement in dealing with the risks of extractive industry. As a result, young people depend on extractive industry operations.
\end{abstract}

KEYWORDS Subpolitik | Youth | Risks | Industry | Strategic Action Fields

\section{PENDAHULUAN}

Ketidakpuasan masyarakat terhadap industri ekstraktif telah melahirkan beragam pergerakan sipil. Sejumlah sarjana telah mengulas berbagai motif kemunculan pergerakan tersebut, seperti persoalan risiko keamanan dan kesehatan (Mancini et al 2018), konflik ekologi akibat serentetan dampak lingkungan (Gonzalez 2018), konflik sosial dengan komunitas lokal (Ventura et al 2017), dan perkembangan diksursus environmental justice sebagai dampak langsung dari aktivitas industri ekstraktif (Osskarson 2018).

Sekalipun dampak negatif industri ekstraktif dirasakan oleh seluruh kelompok usia, anak muda di wilayah beroperasinya proses eksploitasi sumber daya alam tergolong rentan menanggung 'beban ganda' dampak negatif industri. usia, anak muda di wilayah beroper- asinya proses eksploitasi sumber daya alam. Pada satu sisi, anak muda lokal harus menanggung beban sebagai pihak yang kalah bersaing dalam mengakses kesempatan kerja. Sebab, perkembangan industri ekstraktif cenderung menuntut sumber daya manusia yang memiliki kualifikasi pendidikan dan keterampilan memadai sebagai pekerja. Pada sisi lain, anak muda memikul dampak lingkungan yang barangkali tidak hanya dirasakan di saat ini, akan tetapi juga di masa depan. Tanpa adanya upaya restriktif terhadap laju pertumbuhan industri, secara tidak sadar dampak negatif tersebut sangat potensial diwariskan kepada generasi-generasi selanjutnya ketika mereka tidak lagi berkategori kelompok usia muda.

Pemerintah melalui regulasi sejatinya memainkan peran sentral dalam mengatasi dampak 
negatif industri. Namun, pemerintah kerap berada di posisi abu-abu dalam mengatasi persoalan tersebut. Hal ini tidak bisa dipisahkan dari dominasi logika ekonomi yang mengalahkan kalkulasi untung rugi soal lingkungan yang dipikul oleh lintas generasi. Di tengah persoalan tersebut, terdapat individu dan kelompok sosial yang berupaya keluar dari 'kerangkeng besi birokrasi'. Mereka enggan menaruh optimisme terhadap pemerintah untuk berlaku adil ketika dihadapkan pada kepentingan bisnis dan kepentingan masyarakat di wilayah ekstraktif. Mereka lebih memilih untuk mengambil langkah sendiri dengan berjalan di jalur 'politik informal' (Holzer dan Sørensen 2003). Di negara maju, misalnya, organisasi non-pemerintah (Ornop) cenderung muncul sebagai kelompok penekan dampak negatif industri. Berbeda dengan negara maju, di negara berkembang, terutama pada kasus berskala lokal, fenomena seperti itu jarang terjadi. Pasalnya, Ornop di negara berkembang masih tidak lebih terlatih dan terdidik dibandingkan di negara maju. Di tengah kondisi itu, masyarakat lokal kerap turun tangan secara langsung. Pada titik ini, masyarakat memberikan tekanan kepada perusahaan dan pemerintah untuk mengatasi dampak negatif industri (Phuong dan Mol 2004).

Tekanan dan tuntutan masyarakat lokal kepada industri ekstraktif secara terbuka merupakan fenomena baru di Indonesia. Sebagai gambaran, di masa Orde Baru tindakan tersebut sangat kecil terjadi, sebab negara memberikan perlindungan kepada pelaku industri melalui aparat keamanan negara, dan menjadikan mereka sebagai sapi perah (cash cow) untuk kepentingan pejabat. Namun, seiring dengan reformasi dan otonomi daerah, tekanan, tuntutan, dan bahkan perseteruan, antara masyarakat lokal dengan industri ekstraktif muncul ke permukaan (Prayogo, 2010). Belakangan ini, anak muda sebagai bagian dari masyarakat lokal semakin memiliki kepekaan dan potensi sosial dalam menuntut industri ekstraktif di lingkungan tempat tinggal mereka (Swara 2016).

\section{STUDI TERDAHULU MENGENAI ANAK MUDA DAN INDUSTRI}

Mayoritas lokus kajian anak muda dan industri ekstraktif berada di Afrika, terutama negara-negara penghasil migas dan tambang. Berbagai kajian terdahulu di Benua Hitam mengulas sejumlah topik, seperti industri ekstraktif yang tidak signifikan menciptakan lapangan kerja kepada kaum muda, dan pada akhirnya menyebabkan pengangguran (Ackah-Baidoo 2016), respon anak muda terhadap persoalan pengangguran di wilayah industri ekstraktif (Maconachie 2014), ekspektasi anak muda pada industri ekstraktif dan ketidakpercayaan mereka kepada pembuat kebijakan dalam mengelola sumber daya alam (Hoetu dan Kuzu 2011), dan kegelisahan anak muda terhadap kegiatan industri ekstraktif (Chukwuemeka dan Aghara 2010).

Sementara itu, kajian pemuda dan industri boleh dikatakan masih jarang dilakukan di Indonesia. Meski begitu, sejumlah kajian baik fokus pada tema itu atau beririsan dengan tema tersebut sudah muncul. Sutopo et al (2018), misalnya, mendapati bahwa proses transisi dan aspirasi masa depan pemuda di Jawa Tengah, salah satu wilayah industri manufaktur, tidak bisa dipisahkan dari kelas sosial dan aspek gender.

Terkait anak muda dan industri ekstraktif, Lahiri-Dutt dan Mahy (2006) menemukan bahwa perkembangan industri di Sangatta dan Bengalon, Kutai Timur, telah berdampak positif pada tersedianya lapangan pekerjaan, seperti pekerjaan tambang, katering pada pegawai perusahaan, dan pekerjaan jenis informal di sekitar wilayah operasional perusahaan. Dampak positif tersebut dirasakan oleh orang tua, terutama bapak, dari anak muda. Secara bersamaan, kaum muda memiliki harapan tinggi untuk bisa memperoleh penghidupan yang lebih baik di masa depan. Anak muda yang tidak berhasil memenuhi harapan tersebut jatuh pada persoalan narkoba, pelacuran, dan kriminalitas. Harus diakui, Lahiri-Dutt dan Mahy (2006) menye- 
diakan 'data awal' sebagai batu pijakan dalam melihat pemuda dan industri ekstraktif di Indonesia. Namun, kajian tersebut tidak memiliki kerangka konseptual dan analitis yang kuat.

Dalam kasus berbeda, Simatupang dan Swara (2018) menyuguhkan keterlibatan anak muda di Balongan dalam rantai nilai perusahaan migas sebagai pekerja safety man. Tulisan Simatupang dan Swara (2018) sangat kental melihat relasi anak muda dan perusahaan migas dalam kerangka bisnis strategis (strategic business) - perusahaan menciptakan nilai bersama (shared value) dengan mengatasi masalah di tengah masyarakat (Porter dan Kramer 2011). Pada titik ini, keterlibatan anak muda dalam rantai nilai bisnis bukan saja dapat meminimalisir persoalan pengangguran kaum muda di lokasi operasional perusahaan, melainkan juga mengamankan tenaga kerja terampil dalam menekan potensi kecelakaan kerja dalam kegiatan perusahaan itu sendiri. Di samping itu, tulisan tersebut juga tidak menyentuh campur tangan anak muda sebagai kelompok penekan pada perusahaan dan pemerintah.

Berdasarkan penelitian di Tuban, Swara (2016) memperlihatkan bahwa anak muda melalui Karang Taruna menyampaikan aspirasi kepada pemerintah dan perusahaan, dan memberikan legitimasi sosial beroperasi (social license to operate) kepada perusahaan. Hal itu tidak lepas dari ekspektasi anak muda terhadap industri semen di lingkungan tempat tinggal mereka. Ekspektasi tersebut terdiri dari lapangan pekerjaan, lingkungan yang sehat untuk hidup, dan pembangunan desa. Meskipun telah fokus pada pemuda sebagai penekan pemerintah dan perusahaan, Swara (2016) masih melihat muara dari intervensi anak muda dalam kaca mata bisnis (baca: social license to operate). Pada titik ini, anak muda sebagai bagian dari masyarakat lokal merupakan stakeholder perusahaan, dan kegagalan dalam mendapatkan legitimasi beroperasi dapat berdampak buruk pada keberlanjutan bisnis (Freeman 2010).
Sejumlah temuan tersebut cenderung meletakkan mekanisme sosial sebagai produk yang bersifat umum dan tidak melihat pemuda sebagai bagian dari masyarakat risiko (risk society). Dengan menempatkan gerakan anak muda sebagai subpolitik di tengah proses industrialisasi di satu sisi, dan menganalisis gerakan kelompok pada level mikro: aktor dan arena, di sisi lain, artikel ini hadir untuk mengisi kekosongan analisis pada ranah tersebut.

\section{METODE PENELITIAN}

Penelitian ini menggunakan metode kualitatif dengan pendekatan deskriptif. Pengumpulan data dilakukan melalui diskusi kelompok terarah (DKT) dengan pemerintah kelurahan, sejumlah kelompok masyarakat, dan masyarakat biasa. Di samping itu, wawancara juga dilaksanakan dengan individu-individu yang benar-benar mengetahui, memahami, dan memiliki banyak informasi terkait persoalan industri. Berdasarkan kriteria itu tersebut ditetapkan lurah, ketua lembaga pemberdayaan masyarakat (LPM), ketua rukun tetangga (RT), nelayan, dan perwakilan anak muda. Sementara itu, data sekunder digunakan untuk menambah data terkait perkembangan industri di Balikpapan. Berbagai data yang diperoleh tersebut selanjutnya diperbandingkan satu sama lainnya, dan direduksi menjadi data yang relevan sesuai dengan unit analisis penelitian, sehingga data tersebut pada akhirnya disajikan secara deskriptif dalam tulisan ini.

Lokus penelitian ini berada di salah satu kelurahan di Kota Balikpapan, Kalimantan Timur. Lokasi tersebut menarik untuk diketengahkan, sebab mayoritas perusahaan nasional dan internasional yang beroperasi di Kalimantan Timur bermarkas di kelurahan tersebut. Terdapat sekitar 60 perusahaan, baik nasional maupun internasional, yang berkantor di kelurahan itu. Sebagian besar perusahaan tersebut adalah perusahaan pendukung kegiatan pertambangan. 
KERANGKA TEORITIS: SUBPOLITIK DAN STRATEGIC ACTION FIELD

Subpolitik pada mulanya dikembangkan oleh Ulrich Beck, seorang sosiolog Jerman, dalam konteks teori modernisasi refleksif. Teori itu berangkat dari realitas manusia yang telah memasuki modernitas baru, yakni fase kedua modernitas. Menjadi catatan, fase kedua tersebut bukanlah fase post-modern. Pasalnya, modernisasi hanya menjadi lebih rumit, bukan menghilang (Beck et al 2003). Pada fase pertama, modernitas memodernisasi tradisi. Dalam kehidupan pra-modern, misalnya, sumber daya dan kekuatan politik berada di tangan banyak aktor. Namun, modernitas telah mengubah potret itu, sehingga kontrol dimonopoli oleh negara. Secara bersamaan, modernitas juga menghasilkan kemajuan dan kemakmuran bagi masyarakat industri (Holzer dan Sørensen 2001; Holzer dan Sørensen 2003).

Seiring berjalannya waktu, modernisasi mengalami tahapan radikalisasi, dan justru memodernisasi modernitas itu sendiri. Pada titik ini, manusia meninggalkan fase pertama modernitas, dan memasuki fase kedua modernitas. Di balik kisah sukses kemajuan dan kemakmuran, efek samping yang tidak diinginkan (risiko) dari modernitas itu sendiri, seperti krisis ekologi, terakumulasi. Meski begitu, orangorang kerap tidak menyadari efek samping itu, sebab narasi kemajuan dan kemakmuran jauh lebih kuat di benak mereka dibandingkan dengan narasi efek sampingnya. Padahal, tidak seorang pun yang imun dari efek samping tersebut, tidak terkecuali orang-orang yang berhasil menikmati kemajuan dan kemakmuran dari modernitas. Meminjam istilah Beck, kondisi itu disebut dengan 'efek bumerang' (Holzer dan Sørensen 2001; Holzer dan Sørensen 2003).

Di tengah persoalan itu, terdapat individu, kelompok atau bahkan gerakan sosial yang hadir dan berupaya untuk melakukan perubahan sosial dengan cara menantang asumsi dan rasionalitas modernitas. Individu dan kelompok tersebut turun tangan secara langsung menga- tasi persoalan itu melalui protes dan demonstrasi kepada pemerintah dan perusahaan. Meskipun bermuatan politik, tindakan individu atau masyarakat tersebut tidak termasuk dalam politik formal, akan tetapi menjadi bagian politik di luar institusi dan sistem politik dari negara. Inilah yang kemudian disebut dengan subpolitik (Holzer dan Sørensen 2001; Holzer dan Sørensen 2003).

Sebagai respons sosial masyarakat di luar institusi politik formal, subpolitik dapat dilihat melalui dua sudut pandang: pasif dan aktif (Holzer dan Sørensen 2003). Subpolitik pasif dapat dipahami sebagai proses yang tanpa sadar dijalani oleh sekelompok masyarakat yang secara natural mulai mengatur perubahan arah baru yang selaras dengan modernitas. Dalam arti lain subpoltik pasif merupakan gerakan yang dapat dimaknai sebagai pengikut arus modernisasi. Sementara itu, dalam sudut pandang kedua, subpolitik aktif dapat dijelaskan sebagai upaya untuk meredefinisi asumsi-asumsi tradisional tentang modernitas yang cenderung hanya menguntungkan segelintir pihak. Dominannya risiko yang menyertai perubahan sosial, membuat aktor-aktor di luar institusi formal mulai terlibat dalam persaingan untuk memaknai modernitas dalam kacamata mereka yang jauh lebih spesifik dan subjektif. Pada titik ini konflik sosial antar pihak mulai lambat laun tampak ke permukaan (Holzer dan Sørensen 2003).

Sebagai hasil refleksi dari modernisasi, muncul dan berkembangnya subpolitik perlu dilihat secara lebih mendalam melalui pengamatan pada level mikro. Dinamika yang terjadi di level mikro tersebut penting untuk diungkap guna menjelaskan mekanisme sosial yang digunakan sekelompok masyarakat dalam merefleksikan modernisasi. Hal pokok yang perlu diamati ialah arena sebagai setting perubahan sosial di mana sekelompok orang berkontestasi memaknai modernitas berdasarkan kepentingannya. Paradoks yang perlu untuk dibongkar ialah makna subjyektif (subjective meaning) yang mengilhami bekerjanya subpol- 
tik. Fligstein dan McAdam (2012) menjelaskan pemahaman subjektif atas aktivitas sekelompok masyarakat menjadi faktor yang menentukan posisi yang sedang mereka cari di dalam arena sosial. Oleh karenanya, pengamatan mendalam terhadap struktur dan agensi pada kelompok masyarakat menjadi pokok untuk memahami dinamika yang terjadi pada arena yang dimaksud.

Dalam level yang lebih mikro, Fligstein dan McAdam (2011) memperkenalkan Strategic pok masyarakat dan perubahan sosial. Kemunculan teori ini tidak bisa dilepaskan dari studi sosiologi organisasi dan gerakan sosial. Pengamatannya yang diletakkan pada tingkat yang lebih mendasar, membuat SAFs sangat menaruh atensi pada hal-hal yang berkaitan dengan aktor individu di dalam gerakan sosial. Perubahan sosial dalam pendekatan ini perlu dilihat sebagai sebuah proses strategi aksi yang dijalankan melalui interaksi antar satu aktor di dalam organisasi dengan aktor lain di luar organisasinya (Pettinicchio 2013). Hal ini menandakan bahwa aktivisme dalam gerakan sosial dan kelompok kepentingan sebagai sebuah proses politik dan kadang membuat abu-abu ihwal gerakan sosial itu sendiri (Pettinicchio 2012).

Bahkan, jauh sebelum teori ini berkembang, Goldstone (dalam Pettinicchio 2012) telah menyebutkan, karakter yang melekat pada gerakan sosial kontemporer ialah "everyday politic". Indikasinya tampak dari semakin kohesifnya ikatan antara political elite dengan social movement organizations (SMOs). Kecenderungan ini telah menghasilkan aktor masyarakat termasuk political entrepreneur yang memiliki kepentingan untuk menyebarluaskan isu bersama mereka (common issues). Pada titik ini, Fligstein menaruh perhatian khusus, dan mengkerangkai aktivitas tersebut sebagai sebuah "strategi". Layaknya pendekatan institusionalisme (DiMaggio and Powell 1983), teori field yang dikembangkan Fligstein dan McAdam (2011; 2012) mengasumsikan, Strategi pada saat organizational Action Fields (SAFs) untuk memahami kelom-

environment labil dan penuh dengan ketidakpastian, maka unclear actor cenderung mangadopsi norma dan praktik sosial dari aktor dominan. Strategi yang dimaksud oleh Flisgtein dan McAdam sejatinya terletak pada ranah ini, di mana terdapat sejumlah kecil aktor yang menggerakkan komunitas sesuai dengan kepentingannya. Cara pandang ini juga diilhami dari konsep field yang sebelumnya telah lama dikembangkan Bourdieu (1983), di mana terdapat persaingan kekuatan yang tidak seimbang antar aktor di dalam sebuah arena sosial.

Fligstein dan McAdam (2012) menjelaskan terdapat empat hal utama dalam SFAs untuk menganalisis dinamika sosial pada level mikro di kelompok masyarakat atau gerakan sosial. Pertama, aktor akan membagikan pemahaman subjektif mereka tentang aturan main secara sosial sebagai sebuah common understanding. Implikasinya, tujuan gerakan akan diarahkan selaras dengan pemahaman aktor tersebut. Kedua, masing-masing aktor memiliki posisi sosial yang berbeda dan tidak setara, di mana terdapat aktor yang memiliki tingkat legitimasi dan power yang lebih tinggi dibandingkan yang lain. Pada titik ini, political entrepreneur memiliki peran yang signifikan dalam menggunakan pengaruhnya untuk melakukan reframe terhadap diskursus politik di wilayah mereka. Ketiga, aktor yang memahami peran sentral mereka dapat diterjemahkan melalui interaksi dengan aktor lain di luar lingkaran komunitasnya, seperti terhadap institusi politik formal. Keempat, aktor secara subjektif melihat peran mereka dan aktor lain dari sudut pandang posisi mereka di dalam field, sehingga akan muncul banyak perbedaan, bahkan konflik, untuk merumuskan tujuan bersama. Pada titik ini, aktor yang memiliki seperangkat social skill dalam mengakses sumber daya dan kepentingannya akan mampu mengarahkan aktor lain agar dapat sejalan dengan framing issue yang dilakukannya. Inilah yang disebut sebagai mekanisme sosial melalui political entrepenerur, di mana aktor tertentu dapat leluasa menentukan pilihan: mengubah arah pergerakan atau tetap mengikui arus poli- 
tik yang ada (Kauppinen et al 2017; Schneider dan Teske 1992).

\section{TEMUAN DAN ANALISIS \\ Sekilas Transformasi Wilayah}

Seiring dengan penemuan cadangan minyak di Kalimantan Timur pada 1897, wilayah itu secara umum, dan Balikpapan secara khusus, turut mengalami perubahan. Kawasan hutan dibuka untuk membangun jalan raya, dermaga, gudang, perkantoran, barak, dan bungalow. Transformasi itu berlangsung sampai pendudukan Jepang (Wood 1986). Secara umum, pembangunan tersebut bertujuan untuk mempermudah mobilitas pengangkutan minyak dari Balikpapan ke sejumlah wilayah penyimpan cadangan minyak di Kalimantan Timur, dan begitu juga sebaliknya. Sebagian lahan hutan di Balikapapan tersebut merupakan wilayah kelurahan yang menjadi setting pada studi kasus ini.

Pada 1970-an, seiring dengan terbukanya investasi asing di Indonesia, berbagai perusahaan multinasional beroperasi di Kalimantan Timur (Wood 1986). Seperti disebutkan di muka, perusahaan tersebut tidak saja bergerak di bidang eksploitasi migas dan tambang, akan tetapi juga perusahaan pendukung kegiatan migas dan tambang. Berbagai perusahaan berskala nasional dan internasional tersebut berkantor di Balikpapan, dan sebagian besar berada di kelurahan itu. Harus diakui, perkembangan laju industri berkontribusi pada pembangunan Kota Balikpapan. Dana pemerintah kota, misalnya, mengalami kenaikan dari US \$ 0,5 juta pada 1969-1970 menjadi lebih dari US \$ 8 juta pada 1982-1983. Secara bersamaan, pemerintah kota dan pemerintah pusat juga cukup berhasil menyediakan pelayanan sosial, seperti pendidikan SD dan SMP, nutrisi pada anak, dan pusat kesehatan masyarakat (Wood 1986).

Pada periode tersebut, bersamaan dengan laju perkembangan industri ekstraktif, orang-orang dari berbagai wilayah di Indonesia, paling dominan berasal dari Jawa dan Sulawesi Tenggara, pun melakukan migrasi masuk ke
Kalimantan Timur umumnya, dan Balikpapan khususnya, untuk mendapatkan penghidupan yang lebih baik. Pada titik ini, kemiskinan di daerah asal merupakan faktor utama perantau tersebut untuk datang ke Balikpapan. Meski begitu, para perantau itu tidak jarang datang ke Balikpapan dengan pendidikan dan keterampilan yang minim. Akibatnya, mereka sulit bersaing dan terserap sebagai pekerja di berbagai perusahaan. Dihadapkan pada situasi itu, perantau tersebut pada akhirnya bekerja dengan keterampilan yang dibawa dari daerah asal, seperti nelayan, pedagang kecil-kecilan, dan tukang. Bahkan, terdapat pula perantau yang tidak memiliki keterampilan tersebut, dan pada akhirnya menjadi pemulung. Dengan keterbatasan skill dan pendidikan, tidaklah mengherankan jika potret tersebut diwariskan oleh generasi pertama perantau itu kepada generasi selanjutnya. Kehidupan para perantau itu semakin sulit karena perkembangan industri juga berdampak pada peningkatan harga komoditas, persoalan sanitasi, kemacetan, dan penyakit malaria terutama saat musim penghujan (Wood 1986).

Mencerna Pergeseran Subpolitik Anak Muda di Tengah Industrialisasi

Selama satu dekade terakhir, masyarakat lokal menaruh perhatian secara langsung pada perkembangan industri di Balikpapan. Jika pada masa Orde Baru partisipasi masyarakat lokal sangat terbatas (Wood 1986), bersamaan dengan gelombang demokratisasi di tanah air, masyarakat lokal sebagai subpolitik aktif mulai menyuarakan dan menuntut perusahaan dan pemerintah dalam menekan dampak sosial dan lingkungan dari kegiatan industri. Pada konteks setting penelitian ini, yang menarik untuk dicermati adalah kelompok pemuda. Pemuda di wilayah tersebut turut terlibat sekalipun dalam kecenderungan massa yang mengambang dan belum terorganisir. Sejumlah kecelakaan proses industri yang menciderai area perairan dan lahan pertanian masyarakat, telah membuat tuntutan-tuntutan tersebut mulai mengerucut: menolak aktivitas perusahaan ekstraktif. Sayan- 
gnya, hal ini tidak bertahan lama. Di tengah ambisi negara untuk menggenjot pendapatan dari pembangunan sektor sumber daya alam, jumlah perusahaan yang beraktivitas di sana mulai bertambah. Pertambahan tersebut berimplikasi pada perubahan mekanisme sosial masyarakat, khususnya pemuda. Kelompok anak muda lokal lambat laun menggeser tuntutan mereka dan terkesan mulai menerima bahkan mengambil mentah-mentah "distribusi risiko" dari aktivitas industri ekstraktif. Pada titik ini, secara tidaksadar anak muda lokal mulai memikul dampak yang oleh Beck disebut sebagai 'efek bumerang' (Holzer dan Sørensen 2001; Holzer dan Sørensen 2003). Kelompok pemuda mulai memaknai ulang posisi mereka saat dihadapkan kembali dengan fakta industri di wilayahnya. Risiko lingkungan yang selama ini menjadi musuh bersama mulai berubah menjadi upaya untuk mengelola risiko tersebut demi kepentingan yang bersifat ekonomi dan jangka pendek.

Berubahnya tuntutan tersebut juga memproduksi seperangkat strategi aksi yang baru bagi kelompok anak muda lokal pada era pasca Orde Baru. Keterbatasan kesempatan kerja bagi masyarakat merupakan isu yang santer disoroti saat itu. Walaupun menyadari kelemahan pendidikan dan keterampilan bersaing di sektor industri, anak muda mulai menganggap bahwa perusahaan tidak berpihak pada masyarakat lokal, karena faktanya berbagai perusahaan justru lebih memilih menggunakan sumber daya manusia yang berasal dari luar daerah mereka. Tidaklah mengherankan, anak muda sekaedar menjadi penonton di tengah gemuruh pembangunan di wilayah mereka.

Dihadapkan pada persoalan itu, masyarakat, termasuk anak muda, menyampaikan keresahan mereka melalui dialog kepada perusahaan secara langsung. Meskipun perusahaan menyediakan ruang dialog, tindaklanjut untuk menyerap tenaga kerja lokal justru tidak kunjung direalisasikan. Seiring dengan berjalannya waktu, masyarakat, termasuk anak muda, kembali bertemu dengan perusahaan, dan meminta kejelasan dari tindaklanjutnya. Namun, tindaklanjut dari perusahaan tetap tidak ada. Akibatnya, anak muda menekan perusahaan secara langsung melalui aksi demonstrasi. Tekanan itu memang berbuah dengan diberikannya kesempatan kerja sebagai petugas keamanan. Namun, kesempatan kerja hanya diberikan kepada orang-orang yang vokal atau memiliki posisi 'penting' di tengah masyarakat. Pada satu sisi, langkah tersebut boleh dikatakan dapat mengurangi resistensi dari masyarakat, apalagi orangorang yang dipekerjakan memiliki posisi 'penting'. Namun, penyelesaian itu sangat sporadis dan parsial, sehingga menyebabkan tekanan pada perusahaan kembali terulang seiring berjalannya waktu.

Berangkat dari persoalan itu, anak muda mengorganisir diri untuk mengkonsolidasikan kekuatan, dan membentuk Forum Pemuda Bersatu (FPB) pada 2008. Pembentukan organisasi tersebut juga tidak bisa dilepaskan dari ketidakberfungsiannya Karang Taruna sebagai organisasi kepemudaan. Sebagai organisasi sipil yang kemunculannya dari masyarakat sendiri (community based organization), FPB jauh lebih tidak terikat dengan pemerintah. Sebagai perbandingan, Karang Taruna memiliki relasi lebih dekat dengan pemerintah, bahkan pengawasannya berada di tangan pemerintah. Sebab, organisai pemuda itu termasuk organisasi sipil yang lahir karena campur tangan pemerintah secara langsung.

Di bawah wadah tersebut, anak muda mulai mengubah pendekatan mereka terhadap perusahaan. Jika sebelumnya perihal kesempatan kerja anak muda memilih berdemonstrasi, setelah terbentuknya organisasi pemuda itu, anak muda mulai menjalin kerja sama dengan perusahaan untuk mengatasi persoalan pengangguran di kalangan anak muda. Pada titik ini, FPB menyertakan anak muda untuk terlibat dalam pelatihan keamanan dan kebersihan yang diselenggarakan Balai Latihan Kerja (BLK). FPB kemudian menyalurkan anak muda yang telah mengikuti pelatihan itu untuk direkrut perusa- 
haan yang membutuhkan petugas keamanan dan kebersihan. Ikhtiar tersebut jauh lebih strategis, sebab anak muda tidak sekaedar menyadari kelemahan keterampilan mereka, akan tetapi juga mengatasinya dengan ikut dalam pelatihan. Secara bersamaan, upaya itu juga lebih potensial menghasilkan petugas keamanan yang lebih berkualitas dibandingkan petugas keamanan yang tanpa melewati proses pelatihan.

\section{Mencerna Pergeseran Subpolitik Anak Muda di Tengah Industrialisasi}

Selain penyediaan lapangan kerja dan pembangunan infrastruktur, keberadaan perusahaan di kelurahan tersebut juga memberikan kesempatan pada masyarakat, terutama kaum perempuan, untuk membuka usaha, seperti warung makan dan pedagang kecil-kecilan. Secara bersamaan, sejumlah perusahaan juga mulai menerapkan standar etika melalui penerapan program corporate social responsibility (CSR) di sejumlah wilayah terdampak. Hanya saja program CSR yang dimaksud kental bersifat karitas, dan itu pun kerap dilakukan di saat hari-hari besar nasional. Pada titik ini, CSR diterapkan semata-mata untuk kepentingan mendapatkan dukungan secara sosial dari masyarakat lokal. Sekalipun geliat CSRmulai tumbuh, sebagai mana watak aslinya, perusahaan terus memunculkan persoalan lingkungan.

Seperti disebutkan di muka, sebagian besar perusahaan di kelurahan itu adalah perusahaan pendukung industri ekstraktif. Kegiatan operasional perusahaan itu menghasilkan limbah besi. Agaknya fakta yang sama (isu lingkungan) pernah menjadi kegelisahan yang diperjuangankan lewat tuntutan penolakan terhadap aktivitas perusahaan. Namun, mekanisme sosial yang digunakan kelompok pemuda lokal untuk memaknai risiko tersebut mulai bergeser. Seiring perkembangan infromasi dan pengetahuan di level masyarakat lokal, pemuda mulai mengambil langkah untuk menyikapi secara lumrah produksi limbah tersebut dengan mengedepankan logika ekonomi. Mereka menganggap limbah perusahaan sebagai ke- sempatan ekonomi baru yang dapat mendatangkan keuntungan. Melalui FPB, anak muda lokal mulai secara serius menyusun langkah untuk menjadi kelompok profesional pengolah limbah perusahaan.

Pendekatan kemitraan dipilih sebagai mekanisme baru, di mana FPB mulai berubah menjadi kelompok ekonomi yang dapat bermitra dengan sejumlah perusahaan penghasil limbah besi untuk kemudian diolah. Alhasil, setelah kesepakatan "bermitra" telah mereka peroleh, FPB mulai masuk ke dalam pasar ekspor limbah dan menata unit bisnis mereka dari keuntungan yang diperoleh. Keuntungan dari 'bisnis limbah' itu dimanfaatkan oleh FPB untuk membuka usaha jenis lain, seperti air isi ulang, penyewaan tenda dan alat sound system, dan batu bata. Sejumlah usaha tersebut berada di bawah sebuah unit usaha milik masyarakat. Menurut salah satu informan, hasil dari keuntungan berbagai usaha tersebut sudah menghasilkan uang lebih dari Rp3 miliar. Selain mengembangkan usaha, keuntungan juga digunakan untuk mengupah anggota FPB yang mengurusi organisasi, termasuk usaha organisasi. FPB juga memberikan bantuan dari keuntungan usaha kepada panti asuhan di skala lokal dan korban bencana alam di skala nasional.

Dari cerita tentang bisnis pengolahan limbah yang digawangi masyarakat setempat, pemuda secara terang-terangan telah menggeser arah pergerakan mereka sebagai subpolitik pasif di tengah kepungan risiko industri. Narasi sebagai kelompok penekan industri secara tidak sadar mulai berubah secara radikal, bahkan pemuda menjadikan industri ekstraktif sebagai bagian rantai bisnis mereka. Sudah barang tentu, fakta ini menjelaskan bahwa gerakan sosial anak muda di wilayah industri ekstraktif ialah gerakan yang berada dalam ruang yang abu-abu. Makna atas risiko bergeser dengan cepat ketika dialog dengan pihak pencipta risiko (industri) mulai masuk ke ranah ekonomi. Interaksi gerakan sosial yang semakin terbuka kepada seluruh pihak telah membuat perubahan 
mendasar di dalam gerakan sosial itu sendiri (Pettinicchio 2012).

Hal menarik untuk dicermati pada kasus ini ialah meskipun sudah menjalin hubungan bisnis dengan berbagai perusahaan, kelompok anak muda lokal tetap mengambil sikap tegas ketika kegiatan industri di lepas pantai mengancam penghidupan nelayan. Selama 10 tahun terakhir, kegiatan yang berkaitan dengan sumber daya alam di tengah laut beberapa kali telah mengancam penghidupan nelayan dan mencemari lingkungan. Sebagai ilustrasi, aktivitas kapal tengker yang membawa batu bara dan minyak - jaraknya dari bibir pantai sekitar 8-20 kilometer - berjalan hilir mudik selama 24 jam di laut yang berbatasan langsung dengan kelurahan tersebut. Proses pengangkutan tercatat pernah menabrak kapal nelayan. Di samping itu, tumpahan minyak dari pengeboran dan kapal tengker juga pernah terjadi, dan persoalan itu membuat radius mencari ikan bagi nelayan semakin terbatas, terutama nelayan menengah kecil dengan keterbatasan kapal dan alat mencari ikan.

Di persoalan itu, FPB turun tangan dengan memfasilitasi nelayan dengan perusahaan. Secara bersamaan, FPB juga mendesak pemerintah daerah, khususnya DPRD, melalui aksi demonstrasi untuk menaruh perhatian pada persoalan ini. DPRD menyambut aspirasi tersebut, dan bersama dengan FPB, menekan perusahaan untuk mencari jalan penyelesaian dengan nelayan. Berdasarkan perundingan dengan nelayan, perusahaan akhirnya memberikan kompensasi berupa ganti rugi kerusakan alatalat yang dimiliki nelayan untuk melaut, dan lamanya waktu nelayan tidak melaut akibat persoalan yang diakibatkan perusahaan.

Dualitas di dalam subpoltik anak muda pada isu pengelolaan risiko lingkungan ini penting untuk dicermati. Sekalipun mereka bergantung terhadap perusahaan ekstraktif dalam hal pengolahan limbah, sisi aktif subpolitik masih bisa kita cerna melalui keterlibatan aktifnya dalam "menghukum" entitas bisnis yang merugikan masyarakat lain. Namun di sisi lain, mengkategorikan mereka sebagai bagian dari gerakan subpolitik aktif adalah keliru. Mengingat anak muda bukan hanya meredam berbagai tuntutannya soal kerusakan lingkungan yang diakibatkan oleh limbah industri ekstraktif, akan tetapi juga menjadikan perusahaan sebagai pihak yang menyertakan bahan dasar di dalam proses bisnis kelompok anak muda setempat. Pada titik ini, subpoltik di dalam risk society belum mencapai kesepakatannya, terkesan berdiri di dua kaki dan berada dalam ruang yang kabur, sebagaimana pada aktor bisnis sebagai produsen risiko yang kerap kali menjalankan subpolitik aktif dan pasif secara bersamaan demi kepentingan subyektifnya (Holzer dan Sørensen 2001; Holzer dan Sørensen 2003).

Pergeseran Arena: Aktor, Social Skill dan Political Entrepreneur

Di balik cerita tentang perubahan institusi di dalam gerakan sosial anak muda terhadap aktivitas industri ekstraktif, terdapat beragam fakta yang penting untuk diulas pada level mikro. Sebagaimana yang disebutkan di muka, gerakan pemuda lokal diilhami dari konflik terbuka atas perbedaan subjective meaning tentang pertumbuhan industri di wilayahnya. Perbedaan makna antar kelompok formal (negara), aktor bisnis dan kelompok masyarakat tentang arah pembangunan berperan penting dalam menentukan posisi-posisi sosial mereka di tengah kontestasi sosial (Fligstein dan McAdam 2012). Pada tahap awal, pemuda merefleksikan fakta industri sebagai ancaman bagi kelangsungan hidup mereka, sehingga mengambil posisi yang jelas sebagai kelompok penekan. Namun, seiring perkembangannya, field dalam hal ini bukanlah tatanan yang mapan, ia amat sangat tergantung pada aksi individu atau aktor di dalam kelompok masyarakat sebagai bagian dari mikro-kondisi yang merangsang kemunculan dan bahkan transformasi SAFs.

Posisi sebagai kelompok penekan (subpolitik aktif) merupakan pre-existing rules di dalam analisis perubahan arena pada anak 
muda lokal di wilayah studi. Serangkaian perubahan kecil hingga radikal yang terjadi pada arena disebabkan oleh kombinasi sumber daya dan social skill dari aktor tertentu untuk bertransformasi ke arena baru sampai dengan jangka waktu tertentu (Fligstein dan McAdam 2012). Fakta lapangan menunjukkan, kelompok anak muda lokal sangat didominasi oleh seperangkat peranan aktor tertentu. Hal ini terjadi karena aktor tersebut memiliki legitimasi dan power yang lebih dibandingkan aktor lain di dalam kelompok pemuda. Berbeda dengan aktor lain di dalam kelompok, aktor dominan ini memiliki bekal relasi yang lebih dibandingkan yang lain. Sebagai contoh, ia dekat dengan aktor negara, elit politik lokal dan memiliki sumber daya yang baik secara sosial maupun ekonomi. Alhasil, ia kerap kali cukup mudah untuk mendapatkan dukungan sosial dari kelompok elite.

Kecenderungan berubahnya arena juga dapat dijelaskan dari ketidaksetaraan masing-masing aktor di dalam kelompok. Kelompok pemuda yang tergabung dalam FPB didominasi oleh aktor yang unclear secara pemahaman dan makna atas keterlibatan mereka. Hal ini disebabkan karena citra kelompok yang bagi sebagian besar mereka dianggap sebagai sarana memperoleh kesempatan ekonomi dan pekerjaan yang lebih layak. Oleh karena itu, mayoritas diantara mereka bergabung bukan karena upaya untuk memperjuangkan martabat sosio-kultural di tengah kepungan beragam risiko, namun lebih pada hubungan yang saling menggantungkan secara ekonomi.

Aktor yang mendominasi kelompok pemuda ini merupakan bagian dari masyarakat yang dikenal tidak hanya dekat dengan elite, namun juga cukup senior di bandingkan aktor lain di dalam kelompok. Sekalipun melabelkan diri sebagai kelompok pemuda, FPB dipimpin oleh individu yang secara usia tidak tergolong muda. Oleh sebab itu, sangat diwajarkan bila ia mampu memahami aktor lain di luar kelompok yang dapat dijadikan mitra dalam mengakselerasikan kepentingan yang dimiliki. Salah satu dampa- knya ialah kaburnya posisi anak muda sebagai subpolitik di dalam struktur masyarakat risiko.

Peranannya yang begitu sentral dalam mengatur perubahan institusi, juga didasarkan pada faktor kepemilikan modal sosial, ekonomi dan kultural di dalam masyarakat. Dalam sudut pandang class fraction aktor yang memiliki tiga modal sekaligus (sosial, ekonomi dan kultural) akan berada dalam level kelas tertinggi di dalam masyarakat, sehingga distingsi antar aktor akan melanggengkan posisi sosial aktor dominan (Bourdieu dalam Brisson dan Bianchi 2017). Dengan demikian sikap rasa hormat, keseganan dan prestise akan terpusat kepadanya. Selain itu, faktor social skill menjadi salah satu aspek yang menentukan power dan legitimasi kepada aktor tersebut. Kemampuan ini pada dasarnya merupakan kualitas bawaan manusia dan dasar bagi kemunculan konsep menejemen. Seperangkat kemampuan inilah yang mengantarkan aktor dominan sebagai individu yang mampu memobilisasi orang lain untuk tujuan yang dipilih melalui kepemimpinan yang dimiliki (Swartz 2014).

Berangkat dari ketimpangan legitimasi dan power pada masing-masing aktor, individu dominan di dalam kelompok pemuda berupaya menggunakan pengaruhnya untuk melakukan reframe atas diskursus politik di sekitarnya. Aktor dominan melihat terdapat kesempatan ekonomi melalui upaya mengkapitalisasi risiko industri ekstraktif. Peluang ini dikembangkan melalui seperangkat modal yang ia miliki. Praktik ini adalah kecenderungan umum bagi setiap aktor yang dikategorikan sebagai political entrepreneur, karena pada setiap interaksi sosialnya ia selalu mampu melihat opportunities. Hal ini membuat aktor lain in line dengan framing yang diciptakannya. Pada titik inilah, perubahan institusi mulai berproses. Fakta lapangan juga mengungkapkan besarnya peran political entrepreneur dalam mengubah subpolitik anak muda dari gerakan penekan menjadi stakeholder yang sangat bergantung pada aktivitas industri ekstraktif di wilayahnya atau 
oleh Holzer (2008) dijelaskan sebagai perubahan dari stakeseekeer menjadi stakeholder.

Peluang dan Tantangan: Sebuah Refleksi

Berdasarkan berbagai penjelasan sebelumnya, terdapat sejumlah faktor yang dapat mendorong aksi masyarakat, termasuk pemu$\mathrm{da}$, untuk menekan industri di masa depan, dan faktor tersebut sedikit banyak juga berpengaruh di berbagai wilayah di Indonesia, terutama pada kasus berskala lokal. Pertama, gelombang demokratisasi dan desentralisasi. Perubahan rezim pemerintah dari otoritarian dan terpusat menjadi demokratis dan otonomi daerah memberikan ruang kepada warga negara untuk mengoreksi, bahkan menekan aktivitas industri secara langsung. Tindakan anak muda melalui FPB memperlihatkan bahwa anak muda bukanlah untuk menghancurkan atau menjatuhkan perusahaan, akan tetapi sekadar memperoleh kepentingan ekonomi komunitas dari perusahaan (Prayogo 2010).

Kedua, aturan legal yang memaksa atau sukarela menjadi basis legitimasi bagi masyarakat untuk menuntut perusahaan. Secara bersamaan, aturan tersebut juga mencegah masyarakat untuk menuntut perusahaan secara sewenang-wenang jika harapan mereka berada di luar batasan aturan yang berlaku (Achda 2006). Serangkaian aturan di level nasional yang mengatur secara tegas agar perusahaan terlibat dalam mengatasi masalah sosial dan lingkungan di tengah masyarakat sebagai sebuah kewajiban terdiri dari UU No. 22 Tahun 2001 tentang Minyak dan Gas Bumi, UU No. 25 Tahun 2007 tentang Penanaman Modal Asing, dan UU No. 40 Tahun 2007 Perseroan Terbatas. Di samping itu, terdapat pula Peraturan Menteri Lingkungan Hidup No. 06 Tahun 2013 yang mengatur keterlibatan perusahaan pada persoalan sosial dan lingkungan sebagai sebuah kesukarelaan.

Ketiga, perusahaan sangat enggan dianggap tidak bertindak etis dewasa ini. Sebab, tekanan pada perusahaan secara terus menerus berimplikasi negatif pada aset terbesar peru- sahaan, yakni reputasi (Holzer dan Sørensen 2003). Sebagai ilustrasi, eksploitasi besar-besaran Nike terhadap buruh di Indonesia pada akhir 1990-an membuat munculnya tekanan dari lembaga dan aktivis internasional (Kemp 2001). Produk Nike pun diasosiakan dengan produk bisnis yang tidak bertanggungjawab (Herbert 1998), dan kenyataan tersebut berimplikasi buruk pada harga saham dan penjualan perusahaan tersebut (Cushman Jr 1998).

Namun, secara bersamaan terdapat juga sejumlah faktor yang dapat menghambat aksi masyarakat. Kesadaran pada isu lingkungan dan sosial masih lemah, dan keterbatasan jaringan pada ornop yang fokus pada isu sosial dan lingkungan industri. Walaupun kelak kesadaran masyarakat semakin meningkat seiring waktu, sangat mustahil masyarakat memahami dampak buruk dan jangka panjang dari kegatan bisnis (Phuong dan Mol 2004). Apalagi, seperti disebutkan sebelumnya, tuntutan masyarakat cenderung keuntungan ekonomi. Oleh sebab itu, masyarakat lebih bertindak pada jangka pendek, seperti manfaat ekonomi dan menekan dampak lingkungan sesaat. Pada titik ini, mereka belum berorientasi pada jangka panjang, seperti transformasi sebuah wilayah, perubahan mata pencaharian, pergeseran tatanan modal sosial, dan ancaman perubahan iklim, dari kegiatan operasional industri. Kedua, tindakan 'raja-raja kecil', seperti kepala desa, anggota DPRD, dan pejabat daerah, yang mengambil manfaat dari CSR (Zainal 2015) dapat mempengaruhi masyarakat, termasuk anak muda, untuk tidak menekan perusahaan jika persoalan sosial dan lingkungan mencuat. Pada titik ini, mereka lebih berpihak kepada perusahaan dibandingkan kepada masyarakat. Secara bersamaan, tekanan masyarakat juga sangat rentan ditunggangi kepentingan mereka, setidaknya tercermin dari kasus yang diketengahkan pada tulisan ini.

\section{KESIMPULAN}

Tulisan ini telah menyuguhkan narasi 
tentang bagaimana anak muda merefleksikan peranannya sebagai bagian dari subpolitik di tengah risiko yang dihasilkan dari proses industrialisasi. Berdasarkan pengamatan pada salah satu wilayah industri ekstraktif, narasi anak muda lokal sebagai kelompok subpolitik aktif dalam berhadapan dengan ketidakpastian dan sederet risiko yang menimpanya merupakan sebuah pembacaan fakta sosial yang keliru. Fakta mengungkapkan sebaliknya, di mana anak muda terjebak dalam upayanya memaknai risiko itu sendiri. Wacana tentang keberlanjutan kalah dengan kalkulasi ekonomi yang cenderung hanya berlangsung sesaat. Terbukti dari mekanisme sosial yang eksis di wilayah studi, anak muda lokal cenderung mengkapitalisasi risiko atas aktivitas industri.

Pada level mikro, kelompok anak muda lokal adalah potret aktor yang unclear dalam mendefisikan nilai dan praktik sosial sebagai sebuah aktor pergerakan. Peran segelintir aktor justru lebih dominan dibandingkan mayoritas, sehingga kepentingan dan tujuan yang ditetapkan hanya berangkat dari pemaknaan subjektif dari aktor tertentu saja, dan jauh dari aksi yang bersifat kolektif. Hal ini juga yang mendasari pergeseran arena menuju bagian dari masyarakat ekonomi. Risiko yang dulunya dianggap sebagai momok yang merusak kelangsungan hidup masyarakat lokal, justru bertransformasi menjadi alat yang dibutuhkan dan bahkan digantungkan untuk menghasilkan keuntungan ekonomi.

Pemuda perlu merefleksikan ulang peranan mereka dalam mengelola risiko yang sudah, sedang dan akan mereka hadapi di masa mendatang. Kesadaran kritis kelompok muda untuk mendefinisikan persoalan harus tumbuh secara subjektif. Hal ini penting untuk diupayakan, agar demokratisasi di aras lokal dapat diisi oleh gerakan anak muda yang mendorong hadirnya pembangunan sosial ekonomi dan lingkungan yang seimbang, terutama di wilayah yang memiliki risiko degradasi lingkungan dan ketimpangan sosial-ekonomi yang tinggi.

\section{DAFTAR PUSTAKA}

Achda, B. Tamam. 2006. "The Sociological Context of Corporate Social Responsibility Development and Implementation in Indonesia." Corporate Social Responsibility and Environmental Management. 13 (5), pp. 300-305.

Ackah-Baidoo, Patricia. 2016. "Youth Unemployment in Resource-Rich Sub-Saharan Africa: A Critical Review." The Extractive Industries and Society. 3(1), pp. 249-261.

Beck, Ulrich et al. 2003. "The Theory of Reflexive Modernization Problematic, Hypotheses and Research Programme." Theory, Culture \& Society, 20(2), pp. 1-33.

Bourdieu, Pierre. 1983. "The Filed of Cultural Production, or: The Economic World Revesed." Poetics. 12(4), pp. 311-356.

Brisson, Romain and Renzo Bianchi. 2017. "Distinction at the Class-Fraction Level? A Re-Examination of Bourdieu's Dataset". Cultural Sociology, 11(4), pp. 489-535

Chukwuemeka, Emma E. O. and V. N. O. Aghara. 2010. "Niger Delta Youth Restiveness and Socio-Economic Development of Nigeria." Educational Research and Reviews, 5(7), pp. 400-407.

Cushman Jr, John H. 1998. "International Business; Nike Pledges to End Child Labor and Apply U.S. Rules Abroad”. Nytimes. Retrieved July 28, 2019 (https://www.nytimes. com/1998/05/13/business/international-business-nike-pledges-to-end-child-labor-and-apply-us-rules-abroad.html)

DiMaggio, Paul J. and Walter W Powell. 1983. "The Iron Cage Revisited: Institutional Ismorphism and Colective Rationality in Organizational Fields". American Sociological Review. 48(2), pp. 147-260

Fligstein, Neil and Doug McAdam. 2011. A Theory of Fields. Oxford: Oxford University Press.

Fligstein, Neil and Doug McAdam. 2011. "Toward a General Theroy of Strategic Action Fields". Sociological Theory. 29(1), pp. 1-26. 
Freeman, R. Edward et al. 2010. Stakeholder Theory: The State of the Art. New York: Cambridge University Press.

Gonzales, Adrian. 2018. "Control, Fear and Suppression: A Political Ecology of Voice Study into Resource Extraction Indutries- Community Engagement in Peru's Loreto Region." The Extractive Industries and Society An International Journal. 5(3), pp. 319-329

Herbert, Bob. 1998. "In America; Nike Blink". $N_{y}$ times. Retrieved July 28, 2019 (https://www. nytimes.com/1998/05/21/opinion/in-america-nike-blinks.html)

Hoetu, Prosper and Daniela Kuzu. 2011. Youth and Oil \& Gas Governance in Ghana: A Nationwide Survey on the Expectations and Participation of the Youth in Ghana's Oil and Gas Industry. Ghana: Friedrich-Ebert-Stiftung Ghana.

Holzer, Boris and Mads P. Sørensen. 2001. "Subpolitics and Subpoliticians". Researchgate. Retrieved July 28, 2019 (https://www.researchgate.net/publication/282151805_Subpolitics_and_Subpoliticians_Workingpaper)

Holzer, Boris and Mads P. Sørensen. 2003. "Rethinking Subpolitics: Beyond the 'Iron Cage' of Modern Politics?" Theory, Culture \& Society, 20(2), pp. 79-102.

Holzer, Boris. 2008. "Turning Stakeseekers Into Stakeholders: A Political Coalition Perspective on the Politics of Stakeholder Influence." Business \& Society. 47(1), pp. 50-67.

Kauppinen, Iikka et al. 2017. "Social Mecanism and Strategic Action Field: The Example of the Emergence of the Europian Research Area". International Sociology. 23(6), pp. 796-813

Kemp, Melody. 2001. "Corporate Social Responsibility in Indonesia: Quixotic Dream or Confident Expectation?" Digitalcommons.ilr.cornell. Retrieved July 28, 2019 (https://digitalcommons.ilr.cornell.edu/cgi/viewcontent.cgi?referer $=\&$ httpsredir $=1 \&$ article $=1011 \&$ contex $\mathrm{t}=$ codes).

Lahiri-Dutt, Kuntala and Ms Petra Mahy. 2006. Impacts of Mining on Women and Youth in
Indonesia: Two Mining Locations. Canberra: ANU Enterprise.

Maconachie, Roy. 2014. "Dispossession, Exploitation or Employment? Youth Livelihoods and Extractive Industry Investment in Sierra Leone." Futures 62, pp. 75-82.

Mancini, Lucia and Serenalla Sala. 2018. "Social impact Assessment in the Mining Sector: Review and Comparison of Indicator Frameworks". Resource Policy 57, pp. 98-111

Oskarsson, Patric and Heather P Bedi. 2018. "Extracting Environment Justice: Counting Technical Renditions of Pollution in India's Coal Industry". The Extractive Industry and Society. 5(3) pp. 340-347

Pettinicchio, David. 2012. "Institutional Activism: Reconsidering the Indsider - Outsider Dhicotomy". Sociology Compass 6 (6), pp. 499-510

Pettinicchio, David. 2013. "Strategic Action Fields and the Context of Political Entrepreneurship: How Disability Rights Became Part of the Policy Agenda." Research in Social Movement, Conflicts and Change 36:76, pp. 79106

Phuong, Phung Thuy and Arthur P. J. Mol. 2004. "Communities as Informal Regulators: New Arrangements in Industrial Pollution Control in Viet Nam." Journal of Risk Research, 7(4), pp. 431-444.

Porter, Michael and Mark Kramer. 2011. "Creating Shared Value: How to Fix Capitalism and Unleast a New Wave of Growth." Harvard Business Review, 80(2), pp. 56-68.

Prayogo, Dody. 2010. "Anatomi Konflik antara Korporasi dan Komunitas Lokal pada Industri Geotermal di Jawa Barat." Jurnal Sosiologi Masyarakat, 14(1), pp. 25-34.

Schneider, Mark and Paul Teske. 1992. "Toward a Theory of the Political Entrepreneur: Evidence from Local Government." The American Political Science Review. 86(3), pp. 737747.

Simatupang, Erwinton and Vandy Yoga Swara. 2018. "Creating Shared Value di Industri Migas: Pelajaran dari Balongan dalam 
Meminimalisir Pengangguran dan Menekan Potensi Kecelakaan Kerja." Jurnal Pemberdayaan Masyarakat: Media Pemikiran dan Dakwah Pembangunan. 2(1), pp. 63-88.

Sutopo, Oki Rahadianto., Putri, Rani Dwi., dan Karina Larasati K. 2018. "Aspirasi Pemuda Kelas Bawah dan Reproduksi Sosial di Jawa Tengah." Jurnal Studi Pemuda. 7(1), pp. 1-13.

Swara, Vandy Yoga. 2016. "Pemuda Desa di Wilayah Industri: Studi Kasus pada Wilayah Semen di Kabupaten Tuban." Jurnal Analisis Sosial. 20(1\&2), pp.183-196.

Swartz, David L. 2014. "Theorizing Fields". Theory and Society, 43(6), pp. 675-682.

Ventura, Jose and Kety Jauregui. 2017. "Business - Community Retalionship for Extractive Industries: A Case Study in Peru." Brazilian Administration Review. 14(2), pp. 2-24.

Wood, William B. 1986. "Intermediate Cities on a Resource Frontier.” Geographical Review, 76(2), pp. 149-159.

Zainal, Rabin Ibnu. 2015. Mandated Corporate Social Responsibility (CSR) in Indonesia: Institututional and Stakeholder Perspectives. Melbourne: School of Management College of Business, RMIT University. 